\title{
Differential Urinary Proteomic Analysis of Endometrial Cancer
}

\author{
M. KACÍROVÁ ${ }^{1}$, P. BOBER ${ }^{1}$, M. ALEXOVIČ ${ }^{1}$, Z. TOMKOVÁ ${ }^{1}$, S. TKÁČIKOVÁ $^{1}$, \\ I. TALIAN ${ }^{1}$, L. MEDEROVÁ ${ }^{2}$, D. BÉREŠOVÁ ${ }^{2}$, R. TÓTH ${ }^{2}$, I. ANDRAŠINA ${ }^{2}$, \\ Z. KOŽLEJOVÁ ${ }^{3}$, R. KILÍK ${ }^{4}$, R. DIVÍN ${ }^{5,6}$, J. SABO $^{1,6,7}$
}

${ }^{1}$ Department of Medical and Clinical Biophysics, Faculty of Medicine, Pavol Jozef Šafárik University, Košice, Slovakia, ${ }^{2}$ Department of Radiotherapy and Oncology, Faculty of Medicine, Pavol Jozef Šafárik University, East Slovakia Oncology Institute, Košice, Slovakia, ${ }^{3}$ Slovacrin, Faculty of Medicine, Pavol Jozef Šafárik University, Košice, Slovakia, ${ }^{4}$ First Department of Surgery, Faculty of Medicine, Pavol Jozef Šafárik University, Košice, Slovakia, ${ }^{5}$ Faculty of Biomedical Engineering, Czech Technical University in Prague, Kladno, Czech Republic, ${ }^{6}$ Department of Biophysics, Second Faculty of Medicine, Charles University, Prague, Czech Republic, ${ }^{7}$ Czech Technical University in Prague, University Center for Energy Efficient Buildings, Buštěhrad, Czech Republic

Received August 16, 2019

Accepted September 25, 2019

\begin{abstract}
Summary
Endometrial cancer is one of the most frequent gynecological malignancies present in more than $95 \%$ of all uterine cancers. In spite of that, screening of such disease is not commonly performed in clinical practice due to enormous costs and relatively low sensitivity. Therefore, developing an effective screening test to diagnose endometrial cancer at early stages is of great importance for the clinical area of investigation. In this work, we applied urinary proteomics (i.e., bottom-up proteomic approach followed by nano HPLC-ESI-MS/MS) in patients with endometrial cancer, with respect to find proteins aimed for the early diagnostics and screening. According to the results, the significant semi-quantitative changes were observed in urinary proteome of treated patients. The proteins that may be pivotal in pathogenesis of endometrial cancer, like cadherin-1 (CDH1), vitronectin (VTN) and basement membrane specific-heparan sulphate proteoglycan core protein (HSPG2) were downregulated, when compared to the control group. Ultimately, it can be stated that urinary proteomics has a potential for the searching of cancer protein biomarkers based on their altered concentration.
\end{abstract}

\section{Key words}

Endometrial cancer • Proteomics • Urine • Biomarkers

\section{Corresponding author}

J. Sabo, Department of Medical and Clinical Biophysics, Faculty of Medicine, P. J. Šafárik University in Košice, Trieda SNP1, SK-04011 Košice, Slovakia. E-mail: jan.sabo@upjs.sk

\section{Introduction}

Endometrial cancer belongs to the one of the sixth most frequently occurred women's malignant diseases around the world (i.e., 290000 cases/year) (Amant et al. 2015). According to Bokman's classification (Bokhman et al. 1983), there are two subtypes of such a disease, namely: endometrioid adenocarcinoma (Type I) and non-endometrioid carcinoma (Type II). The Type I carcinoma refers to almost $90 \%$ of all endometrial cancers. Regarding its characteristics, Type I is estrogens-dependent and there is a good prognosis for the early diagnosis. On the other hand, Type II is a highly aggressive, non-estrogensdependent and unfortunately often diagnosed at higher degree of progression. The Type II tumors involve serous and clear-cell carcinomas as well as carcinosarcomas (Hussein and Soslow 2018, Mittal et al. 2016).

Nowadays, proteomics has taken a forefront attention in search of potential protein disease biomarkers. These unique substances can provide valuable information of ongoing/actual processes related to particular pathological pathways, performed on molecular level. To date, investigation of potential protein biomarkers of endometrial cancer has been focused mainly upon blood serum (Farias-Eisner et al. 2010, Takano et al. 2010) and/or tissues (Li et al. 2010, 
Maxwell et al. 2011). Regarding other biological samples, urine provides several benefits over blood or solid biological samples (tissues), like non-invasivebased sampling in large quantities repeated as many times as necessary. However, so far, contributions to testing urine samples for searching of protein biomarkers of endometrial cancer have been poor.

In this work, we used urinary proteomics to monitor semi-quantitative changes of proteins in patients with endometrial cancer compared to control group. The basic pathophysiological role of potential protein biomarkers was evaluated.

\section{Methods}

\section{Biological material}

The research was approved by the Ethics Committee of the East Slovak Oncology Institute, Košice, Slovakia, and the Ethics Committee of the Medical Faculty, P. J. Šafárik University, Košice, Slovakia.

Five endometrial cancer patients (ECP) and seven healthy female individuals (control group), were included in the study. The first and second morning urine samples were taken from ECP, collected by spontaneous urination prior to surgery (performed at the Department of Gynaecology, East Slovak Oncology Institute, Košice, Slovakia). Table 1 provides all necessary characteristics of ECP. The control group included women feeling subjectively healthy. The Combur test (Roche Diagnostics) within the reference limits (specific weight, $\mathrm{pH}$, leukocytes, nitrites, proteins, glucose, ketones, urobilinogen, bilirubin, blood), was used to monitor their analytes. In the time, i.e., when the samples were taken, the control group had not suffered any severe endometrial disease.

Table 1. Characterization of patients with endometrial cancer

\begin{tabular}{|c|c|c|c|}
\hline & Age & Histologic types & Type \\
\hline Patient 1 & 56 & $\begin{array}{c}\text { endometrioid } \\
\text { adenocarcinoma }\end{array}$ & I. \\
\hline Patient 2 & 51 & $\begin{array}{c}\text { endometrioid } \\
\text { adenocarcinoma }\end{array}$ & II. \\
\hline Patient 3 & 56 & $\begin{array}{c}\text { endometrioid } \\
\text { adenocarcinoma }\end{array}$ & I. \\
\hline Patient 4 & 56 & $\begin{array}{c}\text { endometrioid } \\
\text { adenocarcinoma }\end{array}$ & I. \\
\hline Patient 5 & 56 & $\begin{array}{c}\text { endometrioid } \\
\text { adenocarcinoma }\end{array}$ & I. \\
\hline
\end{tabular}

\section{Experimental protocol}

Urine samples from both the ECP and control group were centrifuged at $12,000 \mathrm{xg}$ for $30 \mathrm{~min}$ at $4{ }^{\circ} \mathrm{C}$ (AVANTI J-30I centrifuge, Beckman Coulter). For further sample pretreatment, only supernatant was dialyzed overnight, against $3 \mathrm{mmol} / \mathrm{dm}^{3}$ glycine- $\mathrm{HCl}$ dialysis buffer $(\mathrm{pH}=3.2)$. After that, the dialyzed sample was preconcentrated on a CentriVap vacuum concentrator (Labconco). The preconcentrated sample was centrifuged at 30,000xg for $30 \mathrm{~min}$ at $4{ }^{\circ} \mathrm{C}$ (ALLEGRA 64R, Beckman Coulter). The obtained pellet was dissolved in a $50 \mathrm{mmol} / \mathrm{dm}^{3}$ Tris- $\mathrm{HCl}$ buffer $(\mathrm{pH}=8)$ and labelled as Fraction 1. The supernatant was preconcentrated once again to the desired volume, followed by ultracentrifugation at $802,000 \mathrm{xg}$ for $3 \mathrm{~h}$ at $4{ }^{\circ} \mathrm{C}$ using an OPTIMA L-100K ultracentrifuge (Beckman Coulter). At the end of the ultracentrifugation, the three next fractions were collected, as follows: the supernatant collected from the top of the tubes (SN1) was designated as Fraction 2, the supernatant obtained from the bottom of the tubes (SN2) was Fraction 3, and the pellet formed after ultracentrifugation was labelled as Fraction 4. After ultracentrifugation, the pellet was dissolved in $10 \mathrm{mmol} / \mathrm{dm}^{3}$ Tris- $\mathrm{HCl}$ buffer $(\mathrm{pH}=8)$. The supernatants (SN1 and SN2) were preconcentrated to the required volumes and dialyzed overnight, against $3 \mathrm{mmol} / \mathrm{dm}^{3}$ of Tris- $\mathrm{HCl}$ buffer $(\mathrm{pH}=8)$. The following day, each fraction was concentrated to a $\sim 200 \mu \mathrm{l}$ and analyzed.

\section{Measurement of total protein concentration}

The Bradford's assay (Bradford 1976) was used to determine protein concentration in urine samples. The UV-3600 spectrophotometer (Shimadzu) was used to measure radiation absorption at $595 \mathrm{~nm}$. Bovine serum albumin (BSA) standards were used to construct the calibration curve.

\section{In-solution digestion}

After measurement of total protein concentration, in-solution digestion was performed. To each fraction, the $200 \mathrm{mmol} / \mathrm{dm}^{3}$ dithiothreitol (DTT) in $50 \mathrm{mmol} / \mathrm{dm}^{3}$ Tris- $\mathrm{HCl}(\mathrm{pH}=8)$ was added and incubated for $60 \mathrm{~min}$ at $57{ }^{\circ} \mathrm{C}$. Subsequently, the $200 \mathrm{mmol} / \mathrm{dm}^{3}$ iodoacetamide (IAA) in $50 \mathrm{mmol} / \mathrm{dm}^{3}$ Tris- $\mathrm{HCl}(\mathrm{pH}=8)$ was added to the fractions and incubated in the dark for $60 \mathrm{~min}$ at $25^{\circ} \mathrm{C}$. Again, the $200 \mathrm{mmol} / \mathrm{dm}^{3} \mathrm{DTT}$ in $50 \mathrm{mmol} / \mathrm{dm}^{3}$ Tris-HCl $(\mathrm{pH}=8)$ was added to the fractions. The $\mathrm{pH}$ was adjusted to value of 8 using $2 \mathrm{~mol} / \mathrm{dm}^{3} \mathrm{NH}_{4} \mathrm{HCO}_{3}$. In the next step, trypsin was added 
in $1: 10(\mathrm{w} / \mathrm{w})$ ratio and the fractions were incubated at $37{ }^{\circ} \mathrm{C}$ for 24 hrs. After protein digestion, the fractions were acidified to $\mathrm{pH} 4$ with $20 \%$ (v/v) formic acid. Ultimately, the samples were centrifuged on a microcentrifuge (MICROFUGE 22R, Beckman Coulter) at $14,000 \mathrm{xg}$ for $15 \mathrm{~min}$ at $4{ }^{\circ} \mathrm{C}$.

\section{Nano HPLC-ESI-MS/MS analysis}

The fractions were analyzed as technical duplicates by nano HPLC (UltiMate 3000 RSLCnano, Thermo Scientific), which was coupled online with an ion trap electrospray mass spectrometer (amaZon speed ETD, Bruker Daltonik). In nano HPLC analysis, peptides were first preconcentrated on a trap column (Acclaim $\mathbb{R}$ PepMap $100 \mathrm{C} 18$ trap column - $2 \mathrm{~cm}$ x $300 \mu \mathrm{m}$, particle size $5 \mu \mathrm{m}, 100 \AA$, Thermo Scientific) and subsequently separated on an analytical column (Acclaim ${ }^{\circledR}$ PepMap RSLC - $15 \mathrm{~cm}$ x $75 \mu \mathrm{m}$, particle size $2 \mu \mathrm{m}, 100 \AA$, Thermo Scientific) using mobile phase A (98\% water, $2 \%$ acetonitrile containing $0.1 \%$ formic acid) and mobile phase B (95\% acetonitrile, $5 \%$ water containing $0,1 \%$ formic acid). The following gradient elution was set: 4-35\% mobile phase B during $175 \mathrm{~min}$; 35-95\% mobile phase B during $2 \mathrm{~min}$; $95 \%$ mobile phase $\mathrm{B}$ for $15 \mathrm{~min}$ and $95-4 \%$ mobile phase $\mathrm{B}$ for $8 \mathrm{~min}$. Subsequently, the column was equilibrated for $15 \mathrm{~min}$ at $4 \%$ mobile phase B.

The following parameters for the mass spectrometry (MS) were set: enhanced mode, ion charge control (ICC) up to 400,000, maximum accumulation time up to $50 \mathrm{~ms}$ and mass scan range $300-1300 \mathrm{~m} / \mathrm{z}$. For MS/MS spectra, the following parameters were set: Xtreme resolution, ICC up to 500,000 and maximum accumulation time up to $100 \mathrm{~ms}$.

\section{Statistical methods}

The Mascot 2.4 search engine (Matrix Science Ltd.) was used to identify proteins with the following taxonomy parameters: Human, database: SwissProt, fixed modification: carbamidomethylation of cysteine, variable modification: methionine oxidation, enzyme used to cleave proteins into peptides: trypsin, maximum number of cleavages omitted: 2 , false discovery rate (FDR): less than $1 \%$.

Scaffold software (version 4.8.3, trial version) was applied for the semi-quantitative proteomic analysis without labelling ( $99 \%$ probability of occurrence of a protein with at least 2 unique peptides identified; $95 \%$ probability of peptide occurrence), using a quantification method normalized total spectra count and T-test $(\mathrm{p} \leq 0.05)$.

\section{Results}

As mentioned above, the acquired mass spectrometry data from ECP and control group were evaluated via Scaffold software. It has been shown that 181 proteins were identified with different regulations. Further, the label-free quantitative proteomic analysis

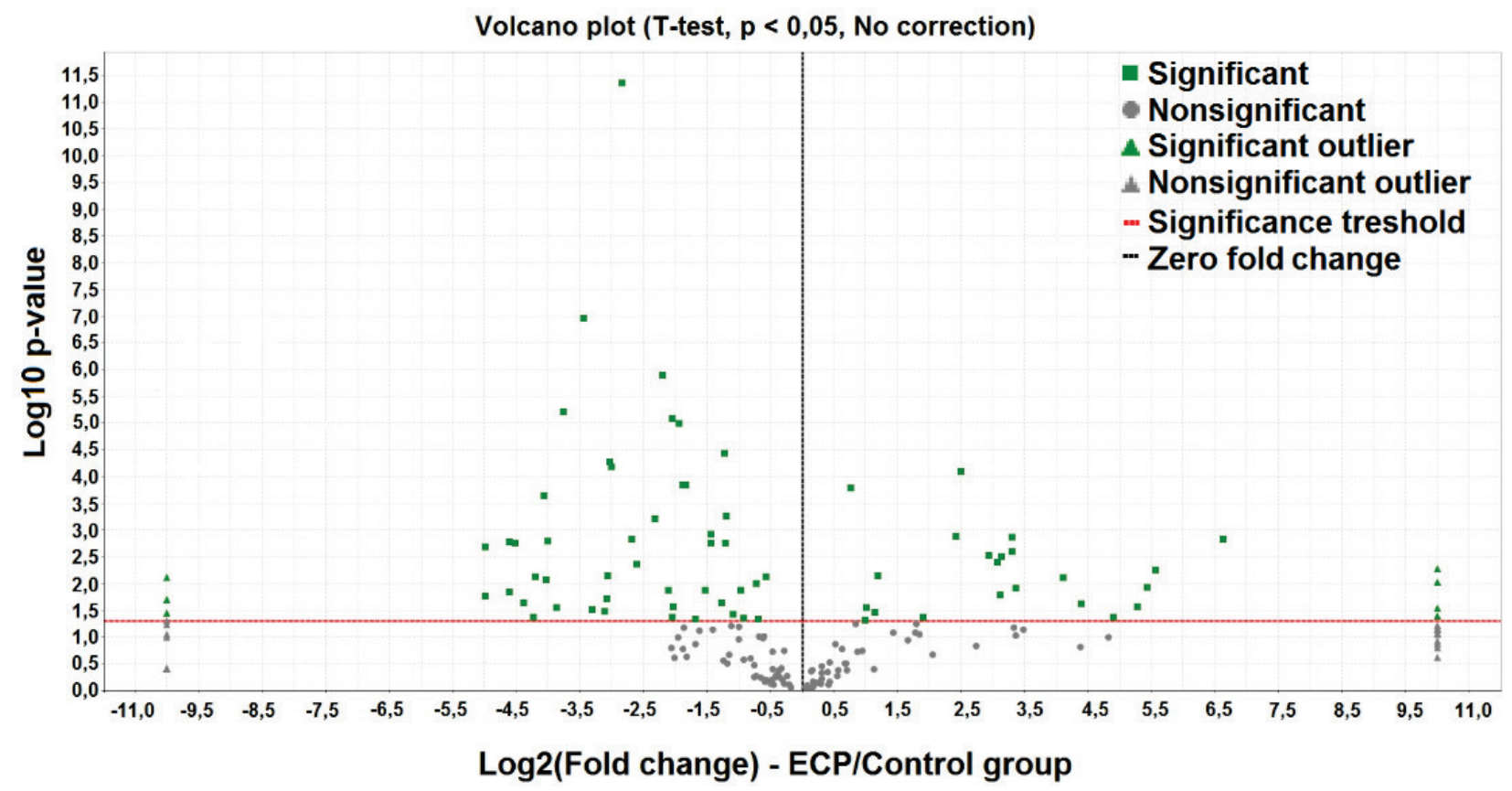

Fig. 1. A volcano plot depicts 181 proteins (i.e., ECP/control proteins) with different regulation. The 76 proteins represent units with underwent significant changes (i.e., T-test, $p \leq 0.05$ ). 


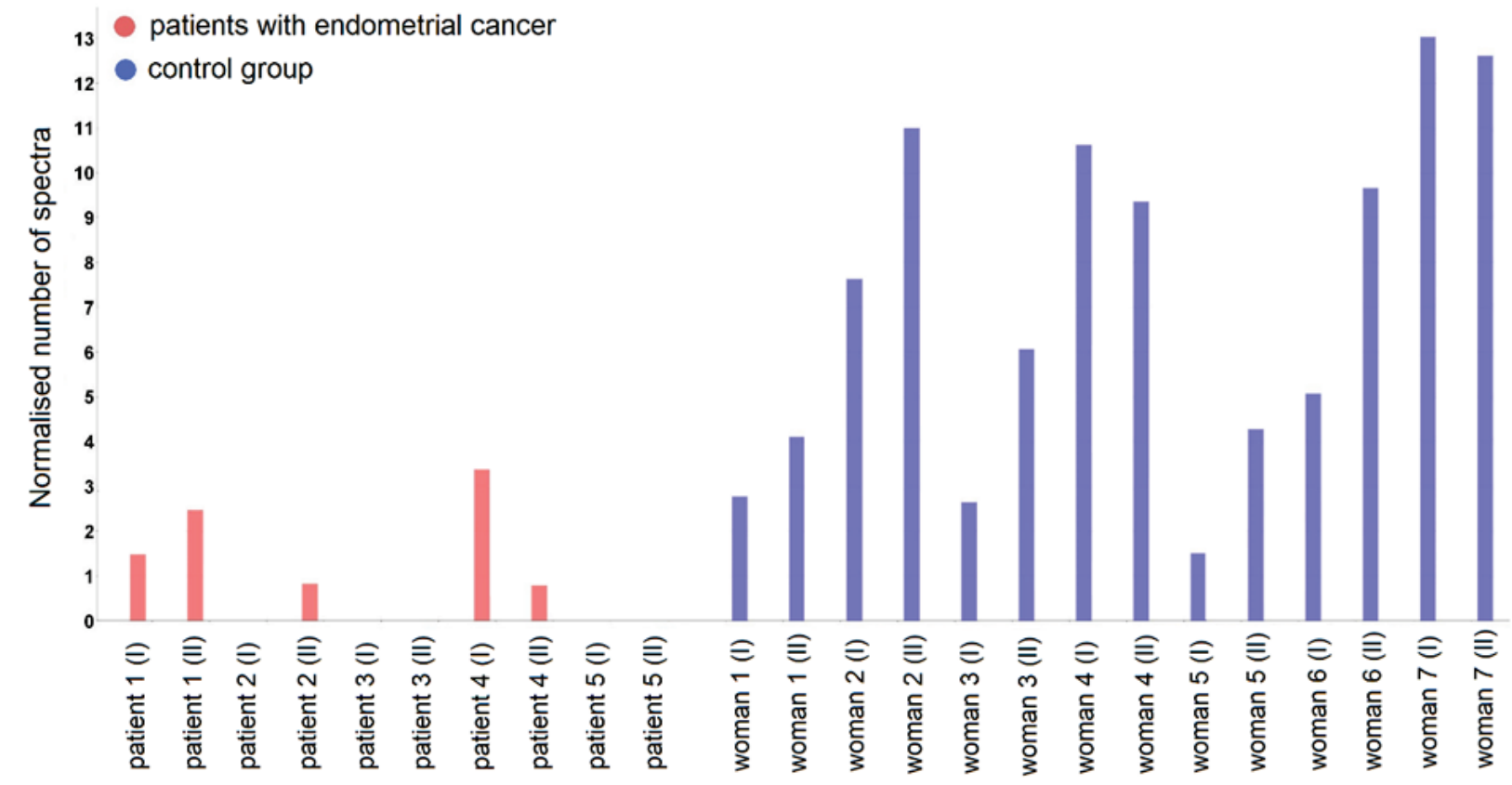

Fig. 2. Down-regulation of cadherin-1 in patients with endometrial cancer compared to the control group. The number I and II refer to the measurement of sample in technical duplicate.

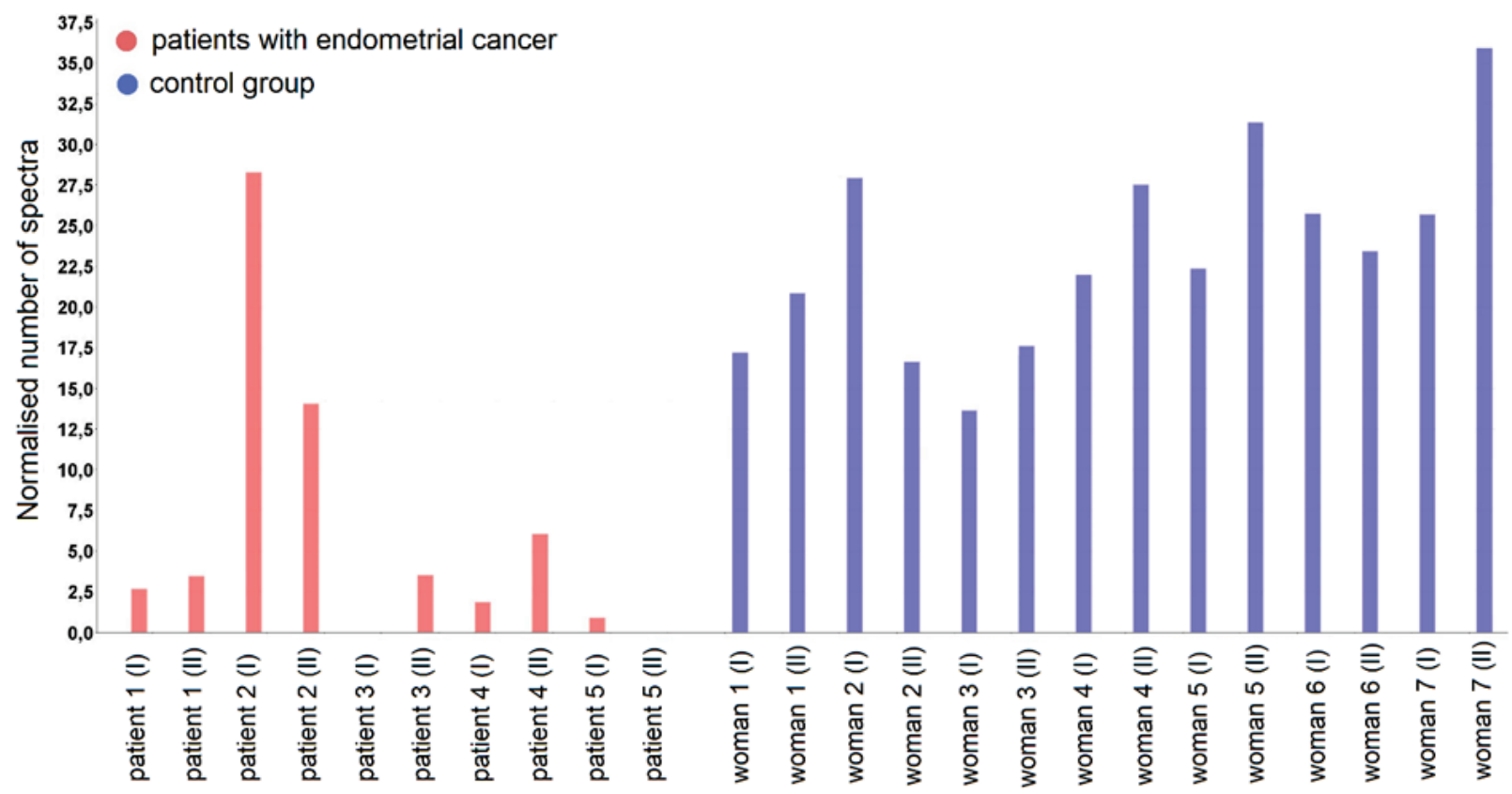

Fig. 3. Down-regulation of vitronectin in endometrial cancer patients compared to control group. The number I and II refer to the measurement of sample in technical duplicate.

was performed based on the Normalised Total Spectral Count quantification method. The statistically significant changes (i.e., which pass $\mathrm{T}$-test $-\mathrm{p} \leq 0.05$ ) were found in 76 proteins. The volcano plot displaying such outcome is depicted in Fig. 1.

Regarding proteins with significant changes, the basement membrane-specific heparan sulfate proteoglycan core protein (HSPG2), vitronectin (VTNC) and Cadherin-1 (CDH1) were further assessed in the manner of their $\log _{2}$ up- and/or down-regulation (i.e., in ECP compared and control group) as these may play the significant role of being potential biomarkers of endometrial cancer. Here, Fig. 2-4 depict outcomes of normalised number of spectra of HSPG2, VTNC and $\mathrm{CDH} 1$, respectively. Results showed that there was a significant down-regulation of all studied proteins in 
ECP when compared with healthy control group.

The calculated T-test, NTS, fold change and $\log _{2} \mathrm{FC}$ data of studied HSPG2, VTNC and CDH1 are also provided in Table 2. To the note, a fold change (FC) was evaluated by comparing the NTS averages of the
ECP and the control group. The results showed that the HSPG2 $\left(\log _{2} \mathrm{FC}=-3.32\right)$ and $\mathrm{CHDH}-1 \quad\left(\log _{2} \mathrm{FC}=-3.32\right)$ proteins represent the same decreases and ultimately VTN $\left(\log _{2} \mathrm{FC}=-1.74\right.$ decrease $)$.

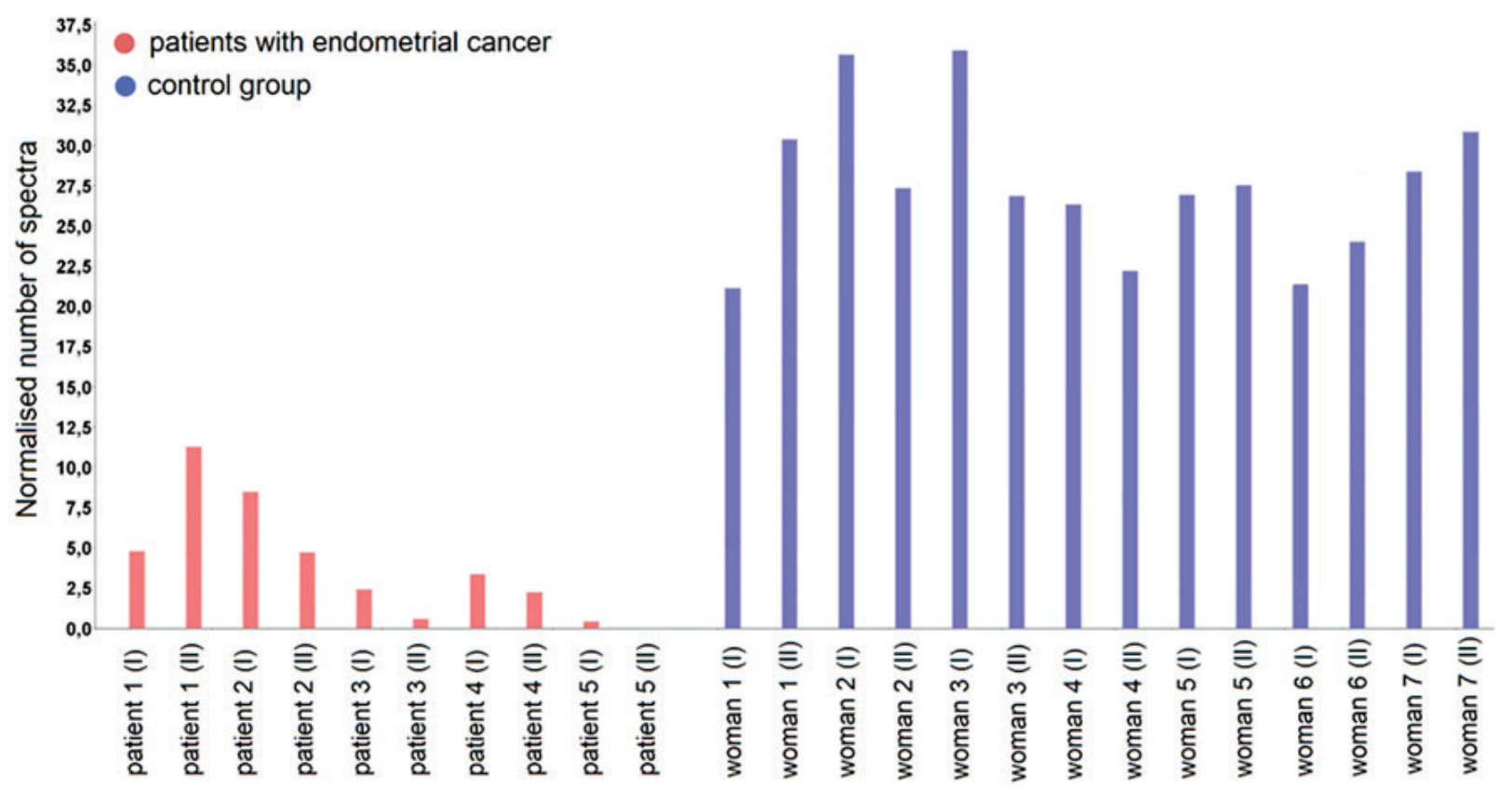

Fig. 4. Down-regulation of basement membrane-specific heparan sulphate proteoglycan core protein specific for basement membrane in patients with endometrial cancer compared to control group. The number I and II refer to the measurement of sample in technical duplicate.

Table 2. Down-regulation of HSPG2, VTN and CDH1 proteins in ECP utilising the Normalised Total Spectra quantification method (T-test, $\mathrm{p} \leq 0.05)$

\begin{tabular}{llcccccc}
\hline Proteins & Accession Number & $\begin{array}{c}\text { MW* } \\
\mathbf{( k D a )}\end{array}$ & $\begin{array}{c}\text { Control NTS * } \\
\text { (average) }\end{array}$ & $\begin{array}{c}\text { ECP* } \\
\text { NTS* } \\
\text { (average) }\end{array}$ & $\begin{array}{c}\text { T-test } \\
(\mathbf{p} \leq \mathbf{0 . 0 5})\end{array}$ & $\begin{array}{c}\text { Fold } \\
\text { Change }\end{array}$ & log2 FC* $^{*}$ \\
\hline HSPG2 & PGBM_HUMAN & 469 & 28.95 & 4.04 & $<0.00010$ & 0.1 & -3.32 \\
$V T N$ & VTNC_HUMAN & 54 & 23.42 & 6.08 & $<0.00010$ & 0.3 & -1.74 \\
CDH-1 & CADH1_HUMAN & 97 & 7.17 & 0.90 & $<0.00010$ & 0.1 & -3.32 \\
\hline
\end{tabular}

*MW-Molecular Weight, *ECP-Endometrial Cancer Patients, *NTS - Normalised Total Spectra, *FC - Fold Change

\section{Discussion}

As mentioned above, the aim of the proposed study was differential urinary proteomics in endometrial cancer patients (ECP) and healthy control group. The changes in concentration of specific proteins between cancer patients and healthy controls have been previously observed in studies using invasive approach and searching for the potential biomarkers of endometrial cancer, breast cancer, ovarian cancer and cervical cancer in tissue and blood serum samples. Thus in this regard, we chose similar evaluation methodology. As indicated in results section, three proteins with significant differences in concentration were observed, namely cadherin-1, vitronectin and basement membrane-specific heparin sulphate proteoglycan core protein. Cadherin-1 (E-cadherin) is a calcium-dependent transmembrane glycoprotein, relevant in establishing adherent 
connections between epithelial cells. It is linked to cytoskeletal actin filaments via $\alpha$ - and $\beta$ - (or possibly $\gamma$-) catenin (Schlosshauer et al. 2002, Xiong et al. 2016). Its role in inhibiting invasion and metastasis is related to prevention of triggering (first step) of the metastatic cascade (Mell et al. 2004). Several studies have shown that decreased concentrations of E-cadherin have facilitated tumor invasion and metastasis in breast cancer (Yoshida et al. 2001), ovarian cancer (Veatch et al. 1994), endometrial cancer (Yalta et al. 2009), and others. Also, elsewhere (Koyuncuoglu et al. 2012), it has been observed, that decreased E-cadherin concentration correlates with adverse prognostic factors in both types (I, II) of endometrial cancers.

Similarly as in E-cadherin, vitronectin protein exhibited lower concentration in endothelial cancer patients (ECP) than in control group as seen in Figure 3. Vitronectin is a main plasma glycoprotein with multiple functions including regulation of cell differentiation, proliferation and morphogenesis (cell adhesion molecule) (Turan et al. 2017). It also belongs among the major components of the extracellular matrix together with collagens, laminin and fibronectin. The tumor microenvironment is an important factor contributing to the promotion of tumorigenesis ( $\mathrm{Mu}$ et al. 2012). It has been pointed out that vitronectin plays an important role in pathophysiological processes and its biosynthesis can be regulated during disease progression. By using ELISA approach, a significant decrease of vitronectin in serum of patients with endometrial and ovarian cancer was observed (Turan et al. 2017). Similar reduced concentration in breast cancer samples was figured out, elsewhere (Kim et al. 2009). Controversially, elevated concentration of vitronectin in patients' serum having ductal breast cancer tested in situ was an outcome as reported by Kadowaki et al. (2011).

Regarding basement membrane-specific heparan sulphate proteoglycan core protein (perlecan) specific for the basement membrane, it is a large protein highly represented in the extracellular matrix and basement membranes of normal tissues and blood vessels (Davies et al. 2004). The perlecan deficiency may promote the diffusion of heparin-binding growth factors, leading to increased tumor growth. Its function in tumor invasion and metastasis depends on the character of the cell. Perlecan may also promote tumor angiogenesis (Jiang et al. 2003). Our results (Fig. 4), indicates reduced concentration of perlekan in EPC compared to control group, what is in agreement with results of Shinyo et al. (Shinyo et al. 2005), who reported that loss of HSPG2 expression may serve as an indicator of aggressive disease potential. Similarly, Hasengaowa et al. (2005) found out that decreased HSPG2 concentration in the basement membrane is associated with tumor progression but is not a sufficient prognostic factor in patients with endometrial cancer.

According to our results, urinary proteomics is a promising tool in the search for potential endometrial cancer biomarkers as it may serve as the approach for clinical early non-invasive diagnostics. The easy-tocollect feature and the possibility of sampling of large volumes of urine sample represent a major advantage over the other biological samples like tissue, plasma, serum and/or cerebrospinal fluid. Therefore, authors believe that urine has a potential to be a sample of choice for diagnostics in future when treating cancer patients' samples.

\section{Conflict of Interest}

There is no conflict of interest.

\section{Acknowledgements}

The authors would like to acknowledge for the financial support of the research The Research Agency of the Ministry of Education, Science, Research and Sport of the Slovak Republic under projects ITMS: 26220120039, the project PON-MIUR, project No. LO1605 the Internal Grant Agency of the Ministry of Health of the Czech Republic 16-29680A and 17-32285A, GAUK 512216 and BIONECA COST action CA1622.

\section{References}

BRADFORD MM: A rapid and sensitive method for the quantification of microgram quantities of protein utilizing the principle of protein-dye binding. Anal Biochem 72: 248-254, 1976.

DAVIES EJ, BLACKFALL FH, SHANKS JH, DAVID G, MCGOWN AT, SWINDELL R, SLADE RJ, MARTINHIRSH P, GALLANGHER JT, JAYSON GC: Distribution and clinical significance of heparan sulfate proteoglycans in ovarian cancer. Clin Cancer Res 10: 5178-5186, 2004. 
FARIAS-EISNER G, SU F, ROBBINS T, KOTLERMAN, REDDY S, FARIAS-EISNER R: Validation of serum biomarkers for detection of early- and late-stage endometrial cancer. Am J Obstet Gynecol 202: 1-5, 2010.

HASENGAOWA, KODAMA J, KUSUMOTO Y, SHINYO Y, SEKI N, NAKAMURA K, HONGO A, HIRAMATSU $\mathrm{Y}$ : Loss of basement membrane heparan sulfate expression is associated with tumor progression in endometrial cancer. Eur J Gynaecol Oncol 26: 403-406, 2005.

HUSSEIN YR, SOSLOW RA: Molecular insights into the classification of high-grade endometrial carcinoma. Pathology 50: 151-161, 2018.

JIANG X, COUCHMAN JR: Perlecan and tumor angiogenesis. J Histochem Cytochem 51: 1393-1410, 2003.

KADOWAKI M, SANGAI T, NAGASHIMA T, SAKAKIBARA M, YOSHIMOTI H, TAKANO S, SOGAWA K, UMEMURA H, FUSHIMI K, NAKATANI Y, NOMURA F, MIYAZAKI M: Identification of vitronectin as a novel serum marker for early breast cancer detection using a new proteomic approach. $J$ Cancer Res Clin Oncol 137: 1105-1115, 2011.

KIM BK, LEE JW, PARK PJ, SHIN YS, LEE WY, LEE KA, YE S, HYUN H, KANG KN, YEO D, KIM Y, OHN SY, NOH DY, KIM CW: The multiplex bead array approach to identifying serum biomarkers associated with breast cancer. Breast Cancer Res 11: R22, 2009.

KOYUNCUOGLU M, OKYAY E, SAATLI B, OLGAN S, AKIN M, SAYGILI U: Tumor budding and E-cadherin expression in endometrial carcinoma: Are they prognostic factors in endometrial cancer? Gynecol Oncol 125: 208-213, 2012.

LI Z, MIN W, HUANG C, BAI S, TANG M, ZHAO X: Proteomics-based approach identified differentially expressed proteins with potential roles in endometrial carcinoma. Int J Gynecol Cancer 20: 9-15, 2010.

MAXWELL GL, HOOD BL, DAY R, CHANDRAN U, KIRCHNER D, KOLLI VS, BATEMAN NW, ALLARD J, MILLER C, SUN M, FLINT MS, ZAHN C, OLIVER J, BANERJEE S, LITZI T, PARWANI A, SANDBURG G, ROSE S, BECICH MJ, BERCHUCK A, KOHN E, RISINGER JI, CONRADS TP: Proteomic analysis of stage I endometrial cancer tissue: Identification of proteins associated with oxidative processes and inflammation. Gynecol Oncol 121: 586-594, 2011.

MELL LK, MEYER JJ, TRETIAKOVA M, KHRAMTSOV A, GONG C, YAMADA SD, MONTAG AG, MUNDT AJ: Prognostic significance of E-cadherin protein expression in pathological stage I-III endometrial cancer. Clin Cancer Res 10: 5546-5553, 2004.

MITTAL P, KLINGLER-HOFFMAN M, ARENTZ G, ZHANG C, KAUR G, OEHLER MK, HOFFMAN P: Proteomics of endometrial cancer diagnosis, treatment, and prognosis. Proteomics Clin Appl 10: 217-229, 2016.

MU AK, LIM BK, HASHIM OH, SHUIB AS: Detection of differential levels of proteins in the urine of patients with endometrial cancer: Analysis using two-dimensional gel electrophoresis and O-glycan binding lectin. Int J Mol Sci 13: 9489-9501, 2012.

SHINYO Y, KODAMA J, HASENGAOWA, KUSUMOTO T, HIRAMATSU Y: Loss of cell-surface heparan sulfate expression in both cervical intraepithelial neoplasm and invasive cervical cancer. Gynecol Oncol 96: 776-783, 2005.

SCHLOSSHAUER PW, ELLESNSON LH, SOSLOW RA: $\beta$-catenin and E-cadherin expression patterns in high-grade endometrial carcinoma are associated with histological subtype. Mod Pathol 15: 1032-1037, 2002.

TAKANO M, KIKUCHI Y, ASAKAWA T, GOTO T, KITA T, KUDOH K, KIGAWA J, SAKURAGI N, SAKAMOTO M, SUGIYAMA T, YAEGASHI N, TSUDA H, SETO H, SHIWA M: Identification of potential serum markers for endometrial cancer using protein expression profiling. $J$ Cancer Res Clin Oncol 136: 475-481, 2010.

TURAN T, TORUN M, ATALAY F, GÖNENÇ A: Assessment of vitronectin, soluble epithelial-cadherin and TGF- $\beta 1$ as a serum biomarker with predictive value for endometrial and ovarian cancers. Turk J Pharm Sci 14: 141-147, 2017.

VEATCH AL, CARSON LF, RAMAKRISHNAN S: Differential expression of the cell-cell adhesion molecule E-cadherin in ascites and solid human ovarian tumor cells. Int J Cancer 58: 393-399, 1994. 
XIONG S, KLAUSEN C, CHENG JC, LEUNG PC: Activin B promotes endometrial cancer cell migration by downregulating E-cadherin via SMAD-independent MEK-ERK1/2-SNAIL signaling. Oncotarget 7: 40060-40072, 2016.

YALTA T, ATAY L, ATALAY F, CAYDERE M, GONULTAS M, USTUN H: E-cadherin expression in endometrial malignancies: Comparison between endometrioid and non-endometrioid carcinomas. J Int Med Res 37: 163-168, 2009.

YOSHIDA R, KIMURA N, HARADA Y, OHUCHI N: The loss of E-cadherin, $\alpha$ - and $\beta$-catenin expression is associated with metastasis and poor prognosis in invasive breast cancer. Int J Oncol 18: 513-520, 2001. 